\title{
CHANNELS FOR PROMOTION OF FASHION BRANDS IN THE ONLINE SPACE
}

\author{
Mykhailo Oklander ${ }^{1}$, Alevtyna Kudina²
}

\begin{abstract}
The article's purpose is to substantiate scientific and applied recommendations for the using of modern digital marketing tools to promote fashion brands. The subject of research is the theoretical foundations of the formation and operation of a system of priority channels for the promotion of brands of light industry enterprises in terms of increasing business risks. Methodology. The methods of scientific abstraction, analysis and synthesis, systemic, dialectical, expert, analogies and structural-functional research methods are used. Results. The study has shown that most of the world's brands in the fashion industry determine e-commerce the main vector of their development. This is due to changes in consumer behaviour and due to the significant impact of the pandemic on the retail sector. There are highlighted adverse factors of development of Ukrainian fashion brands. It has been identified promising channels for promoting fashion brands in the online space. The use of User Journey Map and User Flow is justified to ensure the convenience of using the online store and reduce the amount of time spent on shopping. The key elements of the information architecture of the site are highlighted: cognitive load and mental models. The set of brand measures to encourage users to expand interaction with content (official advertising from the social network) (for Facebook, Instagram, YouTube, TikTok, Pinterest), advertising with well-known bloggers whose audience is similar to the brand's audience (Facebook, Instagram, YouTube), mass following and mass liking (Instagram); mutual PR (Facebook, Instagram, YouTube, TikTok); Giveaway (Instagram)). Brand accounts must be fully consistent with the brand's corporate identity and complement each other. There are shown the advantages of marketplaces in the promotion of goods of the fashion industry and the criteria for their selection in this market. There are determined the specifics of the use of social networks in the promotion of clothing and footwear brands. There are given characteristics of content in social networks Facebook, Instagram, YouTube, TikTok, and Pinterest. There are proposed options for the development of stages of the sales funnel for fashion brands in social networks. It is determined that the strategy of brand development should be based on the specifics of the range in social networks, the portrait of the target audience, the character and DNA of the brand. It is based on the capabilities and goals of social networks. It is stated that with the correct use of resources and opportunities of social networks it is possible to ensure the growth of brand awareness and increase loyalty to it. Practical implications. The results of the study can be used to develop strategies and tactics for promoting fashion brands of Ukrainian companies in the Internet. Value/originality. The value of the article is due to the presence of recommendations for choosing the most effective channels for promoting fashion brands in the online space. There are proposed the functionality of the online store for fashion brands, the criteria for choosing marketplaces, the relevant social networks for the promotion of brands and the direction of their coordination with the company's website.
\end{abstract}

Key words: fashion industry, fashion brands, branding, digital technologies, marketplaces.

JEL Classification: M31

\section{Introduction}

Despite the fact that the concept "brand" is a common and often used term, so far marketers and researchers have not come to a consensus on what a brand is.
There are two different approaches to defining a brand.

The first approach is to define the concept "brand" "through the company". The American Marketing Association suggests the following concept "brand":

\footnotetext{
Corresponding author:

${ }^{1}$ Odessa Polytechnic State University, Ukraine.

E-mail: imt@te.net.ua

ORCID: https://orcid.org/0000-0002-1268-6009

ResearcherID: https://www.researchgate.net/profile/Mikhaylo Oklander

${ }^{2}$ Odessa Polytechnic State University, Ukraine.

E-mail: alevtynakudina@gmail.com
} 
"Brand is a name, term, design, symbol or any other feature that identifies one seller's good or service as distinct from those of other sellers" (Common Language Marketing Dictionary). A similar definition is given by the American researcher P. Kotler. His interpretation of the term "brand" is as follows: "Brand is a name, term, design, symbol or any other feature that identifies one seller's good or service as distinct from those of other sellers" (Kotler, Wong, Armstrong, 2010).

The second approach is to define the brand "through the consumer". This approach considers the concept of brand not from the point of view of the company and its ideas, but from the point of view of the consumer and his or her understanding of a particular brand, manufacturer, product or service. Thus, the main indicator that determines the brand as the qualitative characteristics of the product that differentiate the product on the market. David M. Ogilvy defines a brand as an image of a product that has developed and is stored in the minds of consumers: "A brand is an intangible sum of product attributes: its name, packaging and price, history, reputation and method of advertising. The brand is also a combination of the impressions it makes on consumers and the result of their experience in using the brand" (Pertsiya, 1999).

The novelty of the research topic is to take into account the specifics of the marketing environment of light industry enterprises and justify the choice of relevant channels for promoting fashion brands.

The relevance of scientific solutions allows to form the foundation for increasing market share, the profitability and competitiveness of Ukrainian enterprises in the fashion industry.

The purpose of the article is to substantiate the scientific and applied recommendations for the selection of promising channels for the promotion of fashion brands in the online space.

There were used the methods of scientific abstraction, analysis and synthesis, systemic, dialectical, expert, analogies and structural-functional research methods, which gave the opportunity to develop scientific and methodological approaches to increase sales of light industry enterprises of Ukraine.

It is necessary to solve the following tasks to achieve the purpose:

- to formulate the characteristics of sites with quality customer service for fashion brands;

- to highlight the advantages and disadvantages of marketplaces in the promotion of fashion brands;

- to clarify the criteria for selecting marketplaces for the development of fashion brands using e-commerce;

- to identify the criteria for selecting social networks that should be used to promote fashion brands;

- to justify the format and content of social networks for the development of fashion brands;

- to offer options for the development of stages of the sales funnel for fashion brands in social networks;
- to develop and substantiate a map of interaction of digital resources of fashion brands.

The Ukrainian fashion industry has been actively developing since 2014. During this time, many young and promising brands appeared and began to develop their own retail network. During 2014-2016, some of the brands were able to consolidate their positions in the market, the weaker had to retreat (RAU, 2020).

According to the Ukrainian Association of Light Industry Enterprises as of 2019, there are 2518 enterprises in the light industry in Ukraine, in particular 1669 of them are engaged in producing finished clothing (Ukrlegprom, 2020). Only a few of them become really strong brands with their stable loyal audience. The main reasons for this situation are:

1) The presence on the market of a large number of strong Western TM.

2) The cost of finished products.

3) Low solvency of the population.

4) Lack of sufficient funds for brand development.

5) Narrow assortment.

6) Widespread use of second-hand clothes.

In 2020, the pandemic and closing of physical outlets were another problem for Ukrainian brands. All retailers, including international ones felt the impact of quarantine. The net profit of Inditex, owner of the world-famous clothing brands such as ZARA, Bershka, Pull \& Bear and others, fell by $70 \%$ due to closing of brand stores. At the same time, revenue from online sales increased by $77 \%$ compared to 2019 . Given these figures, the company decided to close 1,200 physical stores and invest 1 billion EUR in online transactions (Kunytskyi, 2021).

According to experts, currently Ukrainian enterprises operating in the field of light industry consider online space to be a priority vector of development. This applies both to the promotion of the brand through marketplaces, and the development of their own online stores. This direction is predictable, because according to the Nasdaq International Securities Exchange, by $2040,95 \%$ of all purchases will be made online (RAU, 2021).

Brand development in e-commerce should be based on digital trends (Sadchenko, Khumarova, 2020), habits and needs of consumers, as well as the use of effective tools to promote fashion brands in the online space. There should be the main channels of development for fashion brands in e-commerce: own website and mobile application, placement of your brand on marketplaces and promotion on social networks.

\section{Website and mobile application}

It is estimated that by 2023, e-commerce purchases will increase from $14.1 \%$ to $22 \%$ (Ecommerce Guide, 2020). E-commerce is an environment that is 
constantly changing under the influence of technology, and therefore requires constant analysis and tracking of trends. This applies to consumer buying habits, the emergence of new ways of delivering goods, the introduction of artificial intelligence, trends in UX-design and others.

The development of an online store includes the following stages (Web-Systems.Solutions, 2021):

1) Analysis of the target audience of the brand.

2) Functional analysis of competing brands' websites.

3) Defining the goals and objectives to be performed by the online store.

4) Drawing up a technical task for the development of the site, which should take into account the necessary structure. The structure of the site, in turn, must be agreed with the SEO-specialist for further promotion of the site in organic production.

5) Development of UI-design that corresponds to the corporate style of the brand.

6) Layout and programming of the site.

7) Online store testing.

8) Website promotion.

When designing an online store, you should take into account the fact that people want physical contact with other people. Unfortunately, e-commerce cannot provide such an opportunity. So, many companies are trying to bring the experience of consumers in physical stores online, making online stores more personalized and design-friendly. One way to achieve this effect is the "recommended" feature, which offers users products based on site searches or pre-orders.

The brand's online store should be intuitively userfriendly. Most stores have a similar structure, the same distribution by category, placement of "buy" buttons and shopping cart icons in the same places. This is due to the fact that the Internet users are already accustomed to a certain structure of the site interface, which allows them to quickly shop on the Internet resources they visit for the first time.

The development of digital technologies has led to inflated consumer expectations. Relevance, convenience and ease of use have become essential components for any online store.

According to a new survey of approximately 2,000 consumers in the United States conducted by digital intelligence platform provider Coveo, $90 \%$ of respondents expect the online shopping experience to be the same or better than in-store. Half of the respondents say that they always have problems when shopping online. $43 \%$ of respondents said they were willing to pay more if they could find the right thing in a few clicks (Berthiaume, 2021). Thus, one of the tasks facing the brand is to ensure the ease of use of the online store and reduce the amount of time it will spend on the purchase of a product.

For this purpose, there are used some tools such as User Journey Map and User Flow. They help recreate the path that users take to meet their goals. These tools help to understand whether all the processes in the product (in this case in the online store) have a logical conclusion (Pong, 2018).

Particular attention should be paid to information architecture (IA), which is the structure of the site and the organization of its content. Information architecture is the creation of a structure for a site, mobile application or other project that allows us to understand where we are as users and where about our position is the information we need (Hillel, 2017).

Information architecture relies on some elements of cognitive psychology to influence how we structure information. The key elements are:

1) Cognitive load is the amount of information that a person can process at any time.

2) Mental models are assumptions that people make before interacting with a website or application. Information is easier to detect when it is in a place that corresponds to the mental model of the user about where it should be (UX Box, 2015).

The main types of structures for sites are linear, linear with deviations, block, tree and tag. For online stores of fashion brands, the best options are tree-like and tag structure (Andrusenko, 2019).

The tree-like structure implies the nesting of one category in another, for each product a separate branch is formed (Figure 1).

Tagged structure involves the creation of individual pages of tags based on parameters: price, promotions, features of use, properties, specific characteristics and so on. Models (by design) of the product can also act as tags for fashion brands.

The advantage of tagging is an increase in the number of pages that can attract additional traffic. This result is achieved by expanding the semantic core: the use of more low-frequency queries. The tagged structure can also be superimposed on the tree. But keep in mind that the site can never be duplicate pages and duplicate products in different categories. This can lead to problems with:

- indexing: the overall size of the site increases, when searching the search bot skips important pages;

- substitution of pages in results: the search engine algorithm can make a duplicate page relevant. The result shows the page which shoule not be promoted;

- if users start linking to a duplicate, the actual promotion page will lose the link weight.

In order for the brand to be able to provide quality customer service through the e-commerce platform, the site must meet the following requirements and recommendations:

\section{Adaptation of the site.}

The online store should be displayed correctly on mobile devices and tablets, as $62 \%$ of smartphone owners made purchases through it (Smith, 2021). 


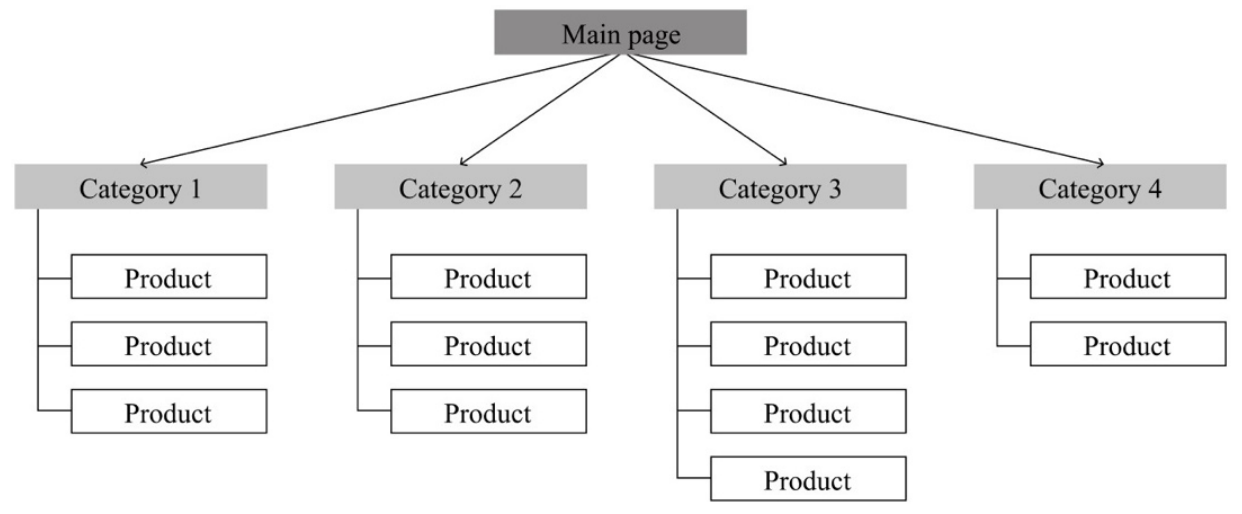

Figure 1. Tree-like structure of the online store

2. There must be an access to the shopping cart at each page.

Usually, the shopping cart is in the upper right corner of the page.

3. The search bar should be as visible as possible.

This will save the user time searching for the product he or she needs.

4. Navigation menu.

This menu helps the client to better navigate the site and easily return to the category he or she needs.

5. Warranties for consumers.

The brand must convince its potential customers of the safety and convenience of shopping on their site, providing information on privacy policies, terms and conditions of delivery of the order, warranties and conditions of return.

Product reviews are also important. This can persuade the visitor to buy the product if he has a quality doubt. Reviews can only be in verbal form, and can be marked with points, which are determined by those who purchased the product. Amazon notes that a large proportion of customers buy the product mostly paying attention to its average rating (Dumaine, 2020).

6. Calls for action

If the brand conducts promotions or sales, information about them should be posted on the main page of the site and encourage (using the appropriate buttons) to go to the section with the promotional product. The most popular option is a button labeled "SHOP NOW".

\section{Attractive photos}

The quality and emotionality of photography is especially important for fashion. Photos posted on the main page should not only be high quality and show the product. They must reflect the DNA of the brand and broadcast a certain way of life that consumers lead or aspire to.

8. Availability of filters and sorting

These features help customers find the product they need as quickly as possible, which in turn improves the customer experience. Colour, size and price filters are a must for clothing brands.

9. The presence of the button "add to wish list"

This allows the buyer to "put aside" the product and buy it later.

10. Goods for additional sale.

A large number of brands use this technique to increase the number of positions in the check. At the bottom of the product card page there are several products that may be similar to the one currently viewed by the customer, or those that may complement the image with this thing (shoes, accessories, etc.). Such products are marked as "Products that you may like".

11. Availability of product description

The product card on the site must indicate the materials the product is made of, the availability of sizes, colours, features of care.

12. Photos from different angles/videos

The client must be sure how the clothes will fit on different sides and whether it fits him or her in all respects. The video adds confidence that the product will look exactly as the brand represents it in real life.

13. Availability of dimensional grid or online fitting

One of the advantages of offline stores over online is that the customer has the opportunity to wear the thing and make sure that it suits him or her. With the development of technology, a similar opportunity has appeared in online stores. The company can install a certain extension on its website, which will allow customers who have entered their parameters (height and body measurements) to understand how a thing of a certain size will fit them. This will not only provide a tax basis for the purchase, but also significantly reduce the number of returns.

You should also optimize your site so that all pages load as quickly as possible. This will increase the possibility of the online store visitor stay and perform the target action. The optimal loading time is 2-3 seconds (Ashmanov and partners, 2020). Optimizing the loading of a web page affects not only 
consumer behaviour, but also its ranking by search engines.

In addition to the fact that the site in the browser must be adapted for the mobile version, companies should already think about developing their own mobile applications. Industry giants such as Nike and Adidas have already invested more than 1 billion USD in the company's digital transformation. They have already created a whole ecosystem of applications where you can buy their products and learn about new products (Bain, 2021). The company also creates its own applications related to running and home training, thus providing useful content for users and increasing brand loyalty.

The promotion of the brand's website and its individual products can be done through SEOoptimization and advertising campaigns in search networks. It should be noted that SEO-optimization is a long-term process and bringing the online store to the top of organic production can take from 4 to 6 months. Search campaigns should be conducted through a wide search for high-frequency queries, and the best option for promoting individual products is Google's trading companies, which allow the user to immediately determine whether a product suits them in appearance and price (Support. Google Ads).

\section{Marketplaces}

One of the ways to promote a brand, increase its visibility and attract new customers is marketplaces. Marketplace is an e-commerce platform, an online e-commerce store that provides information about a product or service of third parties (Wikipedia, 2021). Marketplaces can be of different nature: highly specialized, i.e., to sell one specific type of product (e.g., clothing), or have many areas and categories of products, such as Amazon.

Placing the brand's products on marketplaces has the following advantages:

1. The speed of creating a store.

The brand does not need to create an online store from scratch. All you have to do is download the goods, add the necessary information about the company and follow the policy of the marketplace.

2. Access to a wide audience.

Large platforms are well known and popular with consumers. According to research, the approximate number of visitors to amazon.com, one of the largest marketplaces in the world, is about 2.4 billion per month (RBK, 2020). At the same time, the Ukrainian analogue of prom.ua is visited by approximately 32 million users every month (Portnoy, 2018).

3 . Security guarantees for consumers.

Well-known trading platforms are trusted more than little-known brands, and therefore consumers are more willing to shop there. Because of this, marketplaces can be a great start for small brands in gaining their target audience.

In addition to the advantages, marketplaces have disadvantages, such as:

- high competition on the site;

- dependence on the rules set by the marketplace;

- fewer opportunities to communicate with the client, in contrast to their own online store or social networks; - the need to coordinate promotions and sales.

Despite the disadvantages, well-known brands of clothing and footwear place their products on various marketplaces: Nike and Puma - on Amazon and eBay, Ralph Lauren, Levi's, Calvin Klein, Love Moschino and many others - on Asos, fashion brands of the premium segment - on Farfetch, Netaporter etc. The choice of marketplace depends on its direction and pricing policy of the brand. After all, on the AliExpress platform, consumers go for low-priced products, and on sites such as Mytheresa or Yoox - for clothes of well-known brands operating in the ready-to-wear and ready-to-wear segments.

When choosing a marketplace, one should pay attention to the following:

1) Relevance of the target audience.

The brand must clearly determine whether the target audience of the brand coincides with the audience of the marketplace. For companies working in fashion, platforms that sell goods exclusively in this area are perfect. In Ukraine, there are such sites as kasta. ua (2.86 million visits per month) and lamoda.ua (700 thousand visits per month) (Retailers, 2021).

2) Terms of cooperation:

- the size of the commission;

- frequency of payments to the seller;

- delivery terms;

- the possibility of selling goods at other marketplaces.

3) Conditions and cost of product promotion at the marketplace.

The brand does not spend money on advertising to lead the customer to the marketplace. But inside the site, there are the same rules as in search engines applied. When opening a section with the desired product, customers often view only the first pages. The place where a certain brand product will be placed is influenced by such factors (depending on the characteristics of the marketplace) as: the number of purchases of the item, reviews and evaluations of the product exhibited by buyers. But the brand can also pay for the opportunity to place their products as high as possible in the issue. The cost depends on the marketplace itself and its tariff plans for advertising.

One of the advantages of marketplaces is the large number of users of their mobile applications. Amazon and eBay have been downloaded more than 100 million times on Google Play. As for the applications of Ukrainian marketplaces, Rozetka and Prom were downloaded more than 5 million times, Lamoda - 
more than 10 million times, Kasta - more than 1 million times.

The brand increases its audience and finds new customers more easily, and expands the geography of sales (when placing goods on international marketplaces) by placing the goods of its brand on such platforms.

\section{Social networks}

Today, one of the most effective ways to promote a brand is social networks. They are used by approximately 3.5 billion Internet users (Ukrainian spectrum, 2020). It is important to understand that each of these social networks has its own concept and is targeted to a specific audience. To actively promote fashion brands, you should choose those social networks where you can tell about the company, note your uniqueness and show your range.

For clothing and footwear brands, the best options are social networks such as Facebook, Instagram, YouTube, TikTok and Pinterest. These social networks are ideal platforms for promotion for the following reasons (Figure 2):

1) ability to place visual content;

2) ability to run targeted advertising;

3) a significant number of users.

To promote in each of these social networks, the brand must have its own page, where it will post relevant content with fashion campaigns, brand products, information about events and promotions. The quality and frequency of content are the main drivers for the user of the social network to subscribe to the brand account and then go to the company's website for shopping. Types of content on social networks are presented in Table 1 .

The content of the enterprise should be carefully planned, diverse, interesting, motivating for specific actions and regular. That is why SMM specialists develop a content plan for the account. Keep in mind that every social network has algorithms that are responsible for who and when to show brand content. If the subscriber of the account does not interact with the content of the brand (including views, comments, likes and messages in direct), he gradually ceases to see his content at all. Thus, the brand should encourage users to interact more with the content. This is due to the usefulness of the content and "games", where the subscriber is asked to answer questions (for example, what color dress he ir she likes best).

In order for as many users as possible to subscribe to the account, brands use:

1) Official advertising from the social network (for Facebook, Instagram, YouTube, TikTok, Pinterest);

2) Advertising from famous bloggers, whose audience is similar to the audience of the brand (Facebook, Instagram, YouTube);

3) Mass following and mass liking (Instagram);

4) Mutual PR (Facebook, Instagram, YouTube, TikTok);

5) Giveaway (Instagram).

The development of accounts in social networks is directly related to the sales funnel (Figure 3).

The main task of the marketer and SMM-specialist is to strengthen each of its stages (Table 2).

The company based on the recommendations mentioned above should build its own strategy for brand development in social networks, taking into account its range, portraits of the target audience, the nature and DNA of the brand, etc. In addition, despite the different concepts of social networks, brand accounts should be fully consistent with the corporate style of the brand and complement each other.

We obtain a map of the interaction of digital resources of the brand and given the capabilities and goals of social networks (Figure 4).

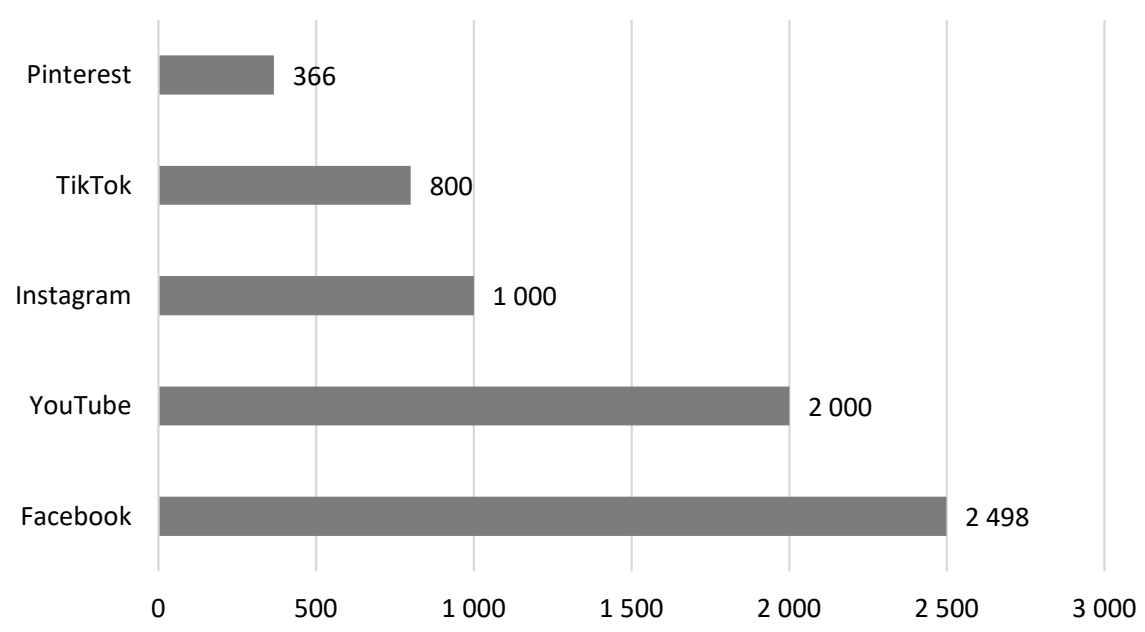

Figure 2. Popular social networks by the number of active users per month relevant for the promotion of fashion brands, million users (Ukrainian spectrum, 2020) 
Vol. 7 No. 2, 2021

Table 1

Types of content on social networks

\begin{tabular}{|c|c|}
\hline Social networks & Types of content \\
\hline \multirow{3}{*}{ Facebook } & $\begin{array}{l}\text { News feed. } \\
\text { Photos and videos of the brand in a 1:1 ratio, describing the product or event, with the possibility of placing an } \\
\text { active link to the brand's website or to a specific product. }\end{array}$ \\
\hline & $\begin{array}{l}\text { Stories. } \\
\text { Photos and videos in a vertical format, where you can present news, new arrivals, promotions, etc. Stories are } \\
\text { available for } 24 \text { hours. }\end{array}$ \\
\hline & $\begin{array}{l}\text { Shops on Facebook. } \\
\text { Products placed in the same way as in the online store, specifying the name, price and description of the product. }\end{array}$ \\
\hline \multirow{4}{*}{ Instagram } & $\begin{array}{l}\text { Feed. } \\
\text { Photos (up to } 10 \text { pcs.), videos (up to } 1 \text { min.). }\end{array}$ \\
\hline & $\begin{array}{l}\text { Stories. } \\
\text { Photos and videos in a vertical format. If the account has more than } 10,000 \text { subscribers, it is possible to place a } \\
\text { link to the site or product of the brand in the online store. }\end{array}$ \\
\hline & $\begin{array}{l}\text { IGTV. } \\
\text { Long-term vertical video. Can be used by fashion brands to publish advertising campaigns, review collections, } \\
\text { fashion shows, etc. }\end{array}$ \\
\hline & $\begin{array}{l}\text { Shopping. } \\
\text { Allows you to mark specific photos in the brand commodity units, which indicate the article and the price of the } \\
\text { goods. When you click on them, the user gets to the product page in the online store. }\end{array}$ \\
\hline YouTube & $\begin{array}{l}\text { Video with the possibility of a detailed description of the product or event without restrictions on links to the } \\
\text { online store and specific products. }\end{array}$ \\
\hline TikTok & Vertical short videos. Used by fashion brands to increase brand awareness. \\
\hline Pinterest & Photos and videos. Format: horizontal or 1:1. Ability to link to the product page in the online store. \\
\hline
\end{tabular}

Table 2

Options for the development of stages of the sales funnel for fashion brands in social networks

\begin{tabular}{|c|c|}
\hline Sales funnel stage & Options for the development of the stage \\
\hline Market volume & $\begin{array}{l}\text { - expansion of the product line; } \\
\text { - expanding the audience; } \\
\text { - entering new markets; } \\
\text { - access to new social networks. }\end{array}$ \\
\hline Advertising campaign coverage & - expansion of targeting the interests of consumers, their social position, etc. \\
\hline Interested in & $\begin{array}{l}\text { - increase the advertising budget on social networks; } \\
\text { - engaging the audience in social networks through offline; } \\
\text { - work with the media; } \\
\text { - collaboration with bloggers. }\end{array}$ \\
\hline Subscribed & $\begin{array}{l}\text { - quality content in a single style; } \\
\text { - use of a "personal brand"; } \\
\text { - placement of all types of content that is possible in a particular social network. }\end{array}$ \\
\hline Engaged audience & $\begin{array}{l}\text { - usefulness of content; } \\
\text { - frequency of publications and time of publications; } \\
\text { - communication with the audience through comments; } \\
\text { - polls and "games" in Stories. }\end{array}$ \\
\hline Made an order & $\begin{array}{l}\text { - providing maximum information about the brand's products (size, colour, materials, etc.); } \\
\text { - publication of product reviews; } \\
\text { - providing answers to subscribers' requests in the shortest possible time (up to } 15 \text { minutes). }\end{array}$ \\
\hline Paid for the order & $\begin{array}{l}\text { - high level of service; } \\
\text { - convenience of placing orders; } \\
\text { - availability of several types of payment. }\end{array}$ \\
\hline
\end{tabular}




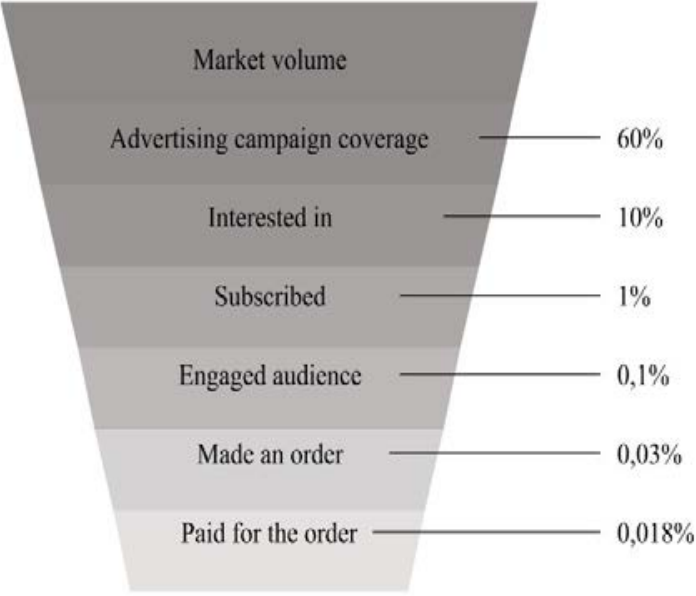

Figure 3. Sales funnel on social networks (Fashion Factory, 2020)

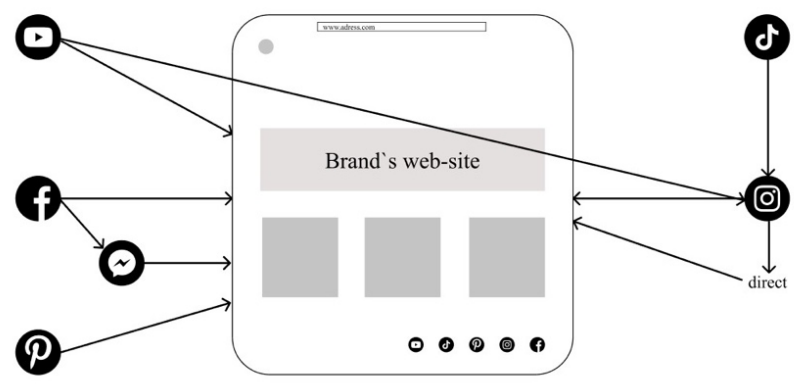

Figure 4. Interaction of digital resources of the brand

The main purpose of marketing is made a profit by meeting the needs of consumers. The main purpose of using modern technologies and resources for fashion brands is increasing brand promotion and online sales. Social networks not only provide interest in the brand. Their main goal is to bring the customer to the brand's online store to buy goods. With the proper use of resources and opportunities of social networks, it is possible to increase brand awareness and loyalty to it, through the provision of useful and quality content, quality guarantees and maximum simplification of the process of buying goods.

\section{Conclusion}

The research shows that global light industry brands such as Zara, Nike, Puma and others are investing billions of dollars in e-commerce to ensure consumer loyalty and increase online sales. This applies not only to the development of online stores, but also personal mobile applications and active activities in social networks.

The article considers three areas of work for fashion brands in the online space: online store, marketplaces, social networks.

There are proposed recommendations for:

1) the functionality of the online store for fashion brands;

2) criteria for selecting marketplaces for sales of brand goods;

3) the most suitable social networks for brand promotion and ways of their interaction with the company's website.

The results of the research can be used to develop a strategy for the emergence of fashion brands in e-commerce and a tactical marketing plan to promote the brand on the Internet.

\section{References:}

Andrusenko, A. (2019). Kak sozdat strukturu dlia internet-magazina [How to create a structure for an online store]. Live page. Available at: https://livepage.pro/knowledge-base/ecommerce-website-structure.html (accessed 24 November 2020).

Ashmanov and partners (2020). Skorost zagruzki saita: kak proverit i uvelichit [Website loading speed: how to check and increase]. Ashmanov and partners. Available at: https://www.ashmanov.com/education/articles/ skorost-zagruzki-sajta/ (accessed 10 December 2020).

Bain, M. (2021). Nike and Adidas are locked in a digital arms race. QUARTZ. Available at: https://qz.com/ 1982171/nike-and-adidas-are-in-a-digital-arms-race/ (accessed 10 March 2021).

Common Language Marketing Dictionary. Brand. Available at: https://marketing-dictionary.org/b/brand/ (accessed 10 December 2020).

Dan Berthiaume (2021). Survey: Online shoppers will pay more for these features. CSA. Available at: https://chainstoreage.com/survey-online-shoppers-will-pay-more-these-features (accessed 10 March 2021).

Dumaine, B. (2020). Bezonomics: How Amazon Is Changing Our Lives and What the World's Best Companies Are Learning from It. NY: Simon \& Schuster.

Ecommerce Guide. (2020) The Future of Ecommerce 2020 Edition. Ecommerce Guide. Available at: https://ecommerceguide.com/guides/ecommerce-future/ (accessed 17 January 2021).

Fashion Factory (2020). Kak postroit voronku prodazh v sotcialnykh setiakh [How to build a sales funnel on social networks]. Fashion Factory School. Available at: https://blog.fashionfactoryschool.com/blog/lajfhaki/marketing/ promotion-chem-vdoxnovlyayutsya-dizajneryi\# cut (accessed 12 January 2021).

Hillel (2017). UX vs UI vs IA vs IxD: chto oznachaiut eti abbreviatury? [UX vs UI vs IA vs IxD: what do these acronyms stand for?]. Hillel IT school. Available at: https://blog.ithillel.ua/articles/ux-vs-ui-vs-ia-vs-ixd-chtooznachayut-eti-abbreviatury (accessed 12 January 2021). 
Kotler, P., Wong, V., \& Armstrong, G. (2010). Osnovy marketinga [Fundamentals of Marketing]. Moscow: Vilyams. (in Russian)

Kunytskyi, O. (2021). Onlain-prodazhi vlasnyka Zara, Bershka ta Pull\&Bear v 2020 rotsi zrosly na $77 \%$ cherez pandemiiu COVID-19. Prybutok upav vnaslidok zakryttia mahazyniv [The online sales of the owner Zara, Bershka and Pull \& Bear in 2020 increased by 77\% due to the COVID-19 pandemic. Profits fell due to store closures]. Forbes. Available at: https://forbes.ua/news/onlayn-prodazhi-inditex-v-2020-rotsi-zrosli-na-77-cherezpandemiyu-kompaniya-ochikue-podalshogo-rostu-10032021-1132 (accessed 12 January 2021).

Pertsiya, V. (1999). Brendmeysteryi [Brandmasters]. Reklamnyie idei - YES! - Advertising ideas - YES!, 2,11. (in Russian)

Pong Nancy (2018). Chto stroit v pervuiu ochered: User Journey Map ili User Flow? [What to build first: User Journey Map or User Flow?]. Medium. Available at: https://medium.com/начинающему-их-Аизайнеру/чтостроить-в-первую-очередь-user-journey-map-или-user-flow-4ece3ed60fb5 (accessed 22 January 2021).

Portnoy, I. (2018). Kak sozdat internet-magazin: 6 preimushchestv marketpleisa [How to create an online store: 6 benefits of a marketplace]. EVO Business. Available at: https://evo.business/6-preimushhestv-marketplejsov/ (accessed 22 January 2021).

RAU (2020). Razvitie vopreki: ukrainskii fashion-riteil prisposablivaetsia k novoi normalnosti [Development in spite of: Ukrainian fashion retail adapts to the new normality]. RAU. Available at: https://rau.ua/ru/news/ ukraynskyj-fashion-rytejl-colliers/ (accessed 12 January 2021).

RAU (2021). Moda onlain: 61\% vsekh internet-prodazh v mire prizrlitsia na odezhdu i obuv [Fashion online: $61 \%$ of all online sales in the world come from clothing and shoes]. RAU. Available at: https://rau.ua/ru/news/ onlajn-prodazhy-odezhda/ (accessed 22 February 2021)

RBK (2020). Sovokupnaia auditoriia 1- krupneishikh marketpleisov sostavliaet pochti 5,5 mlrd. poseshchenii v mesiatc [The total audience of the 10 largest foreign marketplaces amounted to almost 5.5 billion visits per month]. $R B K$. Available at: https://marketing.rbc.ru/articles/12050/ (accessed 22 February 2021)

Retailers. (2021). Samye poseshchaemye internet-magaziny fevralia 2021 goda [Most visited online stores in February 2021]. Retailers. Available at: https://retailers.ua/news/menedjment/11541-samyie-poseschaemyieinternet-magazinyi-yanvarya-2021-goda (accessed 12 January 2021).

Sadchenko, O. V., \& Khumarova, N. I. (2020). Marketynhovi pidkhody formuvannia povedinky subiektiv ekolohoekonomichnoi diialnosti $\mathrm{v}$ umovakh inkliuzyvnoi ekonomiky vrazhen [Marketing approaches to the formation of the behaviour of the subjects of ecological and economic activity in an inclusive economy of impressions]. Market economy: modern theory and practice of management, vol. 19, no. 3(46), pp. 48-67. (in Ukrainian)

Smith, J. (2021). Mobile eCommerce Stats in 2021 and the Future Online Shopping Trends of mCommerce. OuterBox. Available at: https://www.outerboxdesign.com/web-design-articles/mobile-ecommerce-statistics (accessed 12 January 2021).

Support. Google Ads. torgovye kampanii i tovarnye obiavleniia [Shopping campaigns and Product Listing Ads]. Support. Google Ads. Available at: https://support.google.com/google-ads/answer/2454022?hl=ru (accessed 14 February 2021).

Ukrainian spectrum (2020). Naipopuliarnishi sotsialni merezhi v Ukraini ta krainakh svitu u 2020 [The most popular social networks in Ukraine and the world in 2020]. Ukrainian spectrum. Available at: https://uaspectr. com/2020/06/23/najpopulyarnishi-sotsialni-merezhi-v-ukrayini-ta-krayinah-svitu-2020/ (accessed 15 November 2020).

Ukrlegprom (2020). Analitychni materialy haluzi lehkoi promyslovosti [Analytical materials of light industry]. Ukrlegprom. Available at: https://ukrlegprom.org/ua/analytics/(accessed 10 December 2020).

UX Box (2015). Complete Beginner's Guide to Information Architecture. UX Box. Available at: https://www.uxbooth.com/articles/complete-beginners-guide-to-information-architecture/ (accessed 07 December 2020).

Web-Systems.Solutions (2021). Must Have dlya sovremennogo internet-magazina [Must Have for a modern online store]. Web-Systems.Solutions. Available at: https://web-systems.solutions/ru/blog/musthave-dlya-suchasnogointernet-magazynu/ (accessed 25 January 2021).

Wikipedia. Online Marketplace. Wikipedia. The Free Encyclopedia. Available at: https://en.wikipedia.org/wiki/ Online_marketplace (accessed 06 January 2021). 